\title{
ANTHROPOLOGY, DEVELOPMENT AND PUBLIC POLICY ${ }^{1}$
}

\section{Gerald D. Berreman}

\section{INTRODUCTION}

I want to thank the members of the Central Department of Sociology/ Anthropology, Tribhuvan University, and the United States Educational Foundation and its Fulbright program for making it possible for me to visit this fine land and people for half a year. I have done research recurrently for over 35 years in India, mainly in the topographically similar, and culturally related Garhwal Himalayas, but this is my first opportunity to spend a significant amount of time in Nepal.

I have been asked to speak as an anthropologist, about the contributions anthropologists might make to development efforts in Nepal. I will do so, but will go beyond development, to refer more broadly to our actual and potential contributions to public policy formation in general (cf. Campbell, Shrestha and Stone, 1979; Messerschmidt, 1992).

In connection with the Himalayan Film Festival held here in February, sponsored by Himal magazine, I was quoted in the Kathmandu Post of February 27,1994 , as having said in an interview:

"Anthropologists would say most development programmes are harmful. If anthropologists hear of a project, the first thing they would say is 'don't do it'.... You should have people speak for themselves."

(Khanal, p. 4; cf. Shah, 1994)

Although that quotation requires considerable contextualization for its import to be fully understood, I did say something very like that and I do believe it. That is, I believe that many or most anthropologists have come to that conclusion, and I also believe the conclusion to be justified by the evidence -- it 
certainly accords with my own experience (Berreman, 1963a:284-293, 311-335; $1963 \mathrm{~b} ; 1977: 178-182 ; 1979 \mathrm{a} ; 1983 \mathrm{a} ; 1989)$. This is not because development is necessarily bad, but because unfortunately, it usually is bad. Why? Because development is characteristically planned and implemented by people with money to spend, agendas to carry out, and the authority -- the power -- to do so. The fatal flaw is that they are not the people whom it is intended to "develop," and they often know litule about those people, their lives, their needs and their wants.

I will elaborate this point with the thought that anthropologists, as a result of their people-oriented perspective and research, are in a position to make a positive contribution to the situation, if not to remedy it. They are, that is, if they are given the opportunity. What I have to say will apply to a significant extent to sociologists as well, but for simplicity's sake, I will refer explicitly only to anthropologists.

I think it is important to make this last point clear because I am affiliated here with the Central Department of Sociology/Anthropology at Tribhuvan University. In addition, I feel qualified to make that claim because I obtained my Ph.D. in a (then) joint department of anthropology and sociology at Cornell University with sociology as a minor field, and my father was a sociologist, and more importantly in the present context, my wife Keiko Yamanaka is a sociologist! So, I can claim to be sociologically informed, at least by association. I turn now to topic for today.

\section{ANTHROPOLOGY IN NEPAL}

A brochure issued in about 1978 by Tribhuvan University's then newly established Department of Sociology / Anthropology (also sometimes called the Department of Anthropology and Sociology), quoted by Bishnu Bhandari in his article on "The Past and Future of Sociology in Nepal," published in 1990 in the Department's Occasional Papersin Sociology and Anthropology (Bhandari, 1990) had this to say:

"The ultimate purpose [of the department] is to provide students with the theoretical and practical tools that will enable them to assist in the development of the country as planners, administrators, social researchers and teachers". (p.15)

Already, then, the relevance of anthropology to development was made central to the definition of the department.
Bhandari then offered thirteen suggestions as an "Agenda for the Future" of the Department. I will stress four of these here, beginning with his third suggestion:

\section{"3. Define Research Areas to be Covered}

In light of the current situation in Nepal, potential areas [of research] may include poverty, regional inequality, class formation, agrarian class, people's participation, social problems, basic needs, decentralization, women's studies, land tenure systems, population, environment, prescriptive research, the state, etc." (p. 19)

Here again we see a central concern with practical issues, but this time focussing on social and economic issues rather than on "development" as such -- on felt needs of people, rather than (as is most often the case with development programmes) on agendas set from above by government, or from abroad by foreign or international agencies.

Another of Bhandari's agenda items which most interest me today is his ninth:

\section{"9. Shift the Focus of Research from the Descriptive to the} Prescriptive

... There is a need for explanation and a shift from asking 'what' and 'how' to 'why' and 'what must be done.' " (p.19)

This is a principled stance that goes beyond seeking simple facts to addressing issues.

Yet another agenda item that attracts my attention is Bhandari's tenth:

"10. Strike a Balance between the Quantitative and Qualitative [in research methods].

Qualitative as well as quantitative information are the two sides of complete research work. Research in Nepal tends to be heavily biased in one aspect or another. Studies that over emphasize the quantitative can be interpreted in many different ways and consequently used to justify almost anything. An over emphasis on quality often is not taken seriously. Work should be balanced between the two ......." (pp. 19-20)

Finally, the suggested agenda item that may be at once the most controversial 
and the most obviously important is his twelfth:

\section{"12. Making the Discipline Indigenous}

...... Borrowed modes of theory often adulterate the society and culture and prevent understanding our own society and its problems. Sociology has a national character in other countries, so why not here? [He cites Dor Bahadur Bista here].

There is a need to develop methods and techniques suited to local conditions. To achieve this, teaching and research problems must be reoriented. Nepali examples should be given in the classroom. The medium of instruction should be in Nepali, and [appropriate] educational materials need to be made available." (p.20)

It is in the spirit of this last suggestion, "Making the Discipline Indigenous," that I begin my talk with Bhandari's suggestions. For, as I advocate that development must be an indigenous process from formulation through implementation, I also believe that the definition of the resources that inform that process - - including the academic resources -- must be indigenous. This does not preclude borrowing, for all of culture and knowledge is largely shared, but it does mean that such academic borrowing should be indigenously motivated, selected and implemented. That is, it comes from within, according to indigenous definitions of relevance and in response to indigenous circumstances. And, because most societies (including conspicuously Nepal's), are distinctly plural (heterogeneous, with divergent cultures and interests), there must be participation from throughout the society in defining policies and programs -- by all ethnic groups, social classes, castes, genders etc. This, after all, is what democracy is about, to which this nation is now committed.

The well-being of those members of the society who are the most vulnerable, the most poverty-stricken, the most despised, the most remote, the fewest in number is inextricably linked to (and is as important as) that of the most powerful, the most privileged, the most honored and the most plentiful. The fate of the smallest minority is inseparable from that of every other segment of the society. It is absolutely essential that this be recognized and acted upon if this, or any other, nation is to survive in the contemporary world. People who are oppressed or excluded inevitably become angry, resentful people; those who oppress or shun them therefore become vulnerable to their anger and resentment -- increasingly so as technology gives resentful people the means to vent their anger upon their oppressors. That is, the products of oppression are visited upon the oppressors, and as Kardiner and Ovesey concluded nearly fifty years ago in The Mark of Oppression, their classic (although in many ways now outdated) study of consequences of the oppression of Blacks in America, "there is only one way that the products of oppression can be dissolved, and that is to stop the oppression" (Kardiner and Ovesey, 1951:387). This requires, of course, that the social, economic and political systems which are the bases for oppression must be removed. Thus, social justice is not only a moral imperative, it is a practical imperative as well, for it is in the vital personal interest of every individual and group and of the society as a whole (Berreman, 1980).

\section{'DEVELOPMENT' AS 'PROGRESS': CONCEPT AND PROCESS}

With that in mind, I will turn to development as a process: The fascination with development blossomed in the self-described "developed nations" of North America and Europe, following World War II. It was motivated by the desire to rebuild the devastation of war, and to build a world market-place for the victors. The rationale was, of course: "progress," ethnocentrically defined as movement toward a Western (and in most cases capitalist) way of life.

Critics of this view, although out numbered, were significant and vocal. Prominent among them, for example, was Gunder Frank. Basing his analysis largely on his work in Latin America, he maintained that "development" does not improve quality of life, first, because it does not respond to the needs of people, and second, because it magnifies social inequality -- social and economic disparity -- increasing both poverty and wealth and therefore the gap between them, within and between societies (Frank, 1967; 1969).

Based upon their experience in developing societies and in cross-cultural research, anthropologist have come to include many of the most persistent skeptics and critics of development projects and of the very concept of development. This is because anthropologists tend to study, and therefore to be intimately familiar with, those "targeted" by development schemes -- those who are to be developed. That is, they come toknow those whose lives and environments are to be managed -- often are to be exploited -- for development. To know such people is to understand them and to understand them leads one to empathize with them and their problems.

Not only are development and its goals almost always defined, designed and implemented by outsiders but, as a result, whatever benefits may accrue go to those same outsiders or their allies among elites of the targeted societies. This 
is not to say that development is always intentionally exploitative and selfishly motivated, nor that its advocates and practitioners are always thoughtlessly callous. Such plans may actually be believed to be beneficial to the target populations. But because they are not generated from within they are not based on the experience of those to be developed (nor even on significant familiarity wis a result development schemes most often are not weople's cincumstances and needs and therefore have most often responsive to people's circumstanc counter-productive -- ranging from damaging proved to be inappropriate at best, counter-productive - ranging from damaging to devastating -- at worst. For examples, see Bodley, editor, 1988; articles in nearly every issue of the journal Cultural Survival $Q$ uarterly; and such case studies as those by Gross, 1971, and by R. Franke, 1977. Both of the latter are described in Kottak, 1987a: 340-345; and in 1987b:492-497, in the context of two excellent chapters relevant here: "Anthropology and economic development" (Kottak, 1987a: 332-355; 1987b:484-507), and "Applied anthropology" (Kottak, 1987a:356-376; 1987b: 508-528).

Why this dismal record on the part of even well-meaning, benevolently motivated development people and agencies? Quite obviously because of the molicy makers of what constitutes "development," of what constitutes "progress," even of what constitutes a "standard of living."

The standards -- the criteria -- for development are those of Western econolics, of Western technology, of Western styles of life. This is generally true whether the planners and policy makers are Western people or the in positions to become planners and policy makers, regardless of nationality or background, are nearly always those who have been trained (o Western standards, often in Western institutions, and have been western values -- co-opted by what has been termed "academic (1969) or its bureaucratic equivalent. They are, in short, the expatriates, the educated, the affluent, the elite, and in all cases, the Westernized.

Thus, for example, we have the uniquely Westem, but almost universally employed concept of the "Gross National Product" (measured by the monetary value of commercial production) as a measure of prosperity, of desirable "development." In fact, we have the broader, but equally ethnocentric concept of "economic growth" as a measure of economic health -- an endless process of striving in an with a as healthy, desirable, even necessary, rather than a concept of a stable economy, fulfilling the needs and wants of the members of a society, as was the case for more than 99 per cent of human existence, and as is the case for most of the people alive in the world today. As if ordinary people will benefit from the kinds of circumstances that define a "growing" economy, or a "healthy" gross national product. As if anyone but the lucky and ruthless venture capitalists can benefit from such circumstances. As if profits put in at the top of the economic pyramid will "trickle down" to the wage laborers, to the subsistence farmer, to say nothing of the genuinely poor. In short, as if consumption and accumulation were measures of well-being.

One of the most clearly and passionately stated discussions of the implications f these phenomena is to be found in an essay by Ivan Illich, aimed at an A therican audience but entitled (with intentional irony) as if it were directed to he 'Developed' Countries" (Illich, 1969). He writes from a position very similar to my own, stating near the end of his essay that:

"There is a normal course for those who make development policies, whether they live in North or South America, in Russia or Israel. It is to define development and to set its goals in ways with which they are familiar, which they are accustomed to use in order to satisfy their own needs, and which permit them to work through the institutions over which they have power or control. This formula has failed, and must fail. There is not enough money in the world for development to succeed along these lines, not even in the combined arms and space budgets of the super-powers" (p. 24).

He begins the essay by describing the self-defeating limitations to the imagination of developers in the context of the "developed" world from which they come:

"So persuasive is the power of the institutions we have created that they shape not only our preferences, but actually our sense of possibilities. We have forgotten how to speak about modern transportation that does not rely on automobiles and airplanes. Our conceptions of modern health care emphasize our ability to prolong the lives of the desperately ill. We have become unable to think of better education except in terms of more complex schools and teachers trained for ever longer periods. Huge institutions producing costly 
services dominate the horizons of our inventiveness.

"We have embodied our world view into our institutions and are now their prisoners. Factories, news media, hospitals, governments, and schools produce goods and services packaged to contain our view of the world. We -- the rich -- conceive of progress as the expansion of these establishments. ......

"In less than a hundred years industrial society has molded patent solutions to basic human needs and converted us to the belief that man's needs were shaped by the Creator as demands for the products we have invented" (p. 20).

Further along in his argument he continues:

"[The] concrete consequences of underdevelopment are rampant; but underdevelopment is also a state of mind, and understanding it as a state of mind, or as a form of consciousness, is the critical problem. Underdevelopment as a state of mind occurs when mass needs are converted to the demand for new brands of packaged solutions which are forever beyond the reach of the majority....... [It is exemplified in] the translation of thirst into the need for a Coke .... [and in] the intense promotion of schooling [which] leads to so close an identification of school attendance and education that in everyday language the two terms are interchangeable. Once the imagination of an entire population has been ... indoctrinated to believe that school has a monopoly on formal education, then the illiterate can be taxed to provide free high school and university education for the children of the rich" (pp. 2122).

\section{He concludes with his recommendations:}

"Defining alternatives to the products and institutions which now pre-empt the field [of 'development'] is difficult, not only because these products and institutions shape our conception of reality itself, but also because the construction of new possibilities requires [an extraordinary] concentration of will and intelligence ... [on what] we have become accustomed over the last century to call research." (p.23)

He hastens to make clear that he is not referring to basic research, although it has its place and its value, nor is he writing "of the billions of dollars annually spent on applied research [that is] largely spent by existing institutions on the perfection and marketing of their own

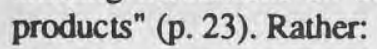

"I am calling for research on alternatives to the products which now dominate the market.

".... This counter-research on fundamental alternatives to prepackaged solutions is the element most critically needed if the poor nations are to have a liveable future. ... [It must be realistic, taking] as one of its assumptions the continued lack of capital in the Third World.

"The difficulties of such research are obvious. The researcher must first of all doubt what is obvious to every eye. Second, he must persuade [or pressure] those who have the power of decision to act against their own short-run interests .... And, finally, he must survive as an individual in a world he is attempting to change fundamentally so that his fellows among the privileged minority see him as a destroyer of the very ground on which all of us stand" (pp. 23-24).

That is the formidable, visionary task to which Illich devoted his life -- a task he considered essential if human kind are to survive with lives worth living. I urge anyone involved in development, interested in or concerned about the process, to read that essay.

Returning to my own rermarks, I would say, in sum, that "progress" as it is usually conceived relies upon bigness and complexity of ever increasing proportions; it relies on political centralization, bureaucracy, social hierarchy, specialization of labor combined with heavy reliance on capital intensive, high energy technology; on market economies artificially creating "needs" and the dependency they generate through massive use of advertising (Bodley, 1967: esp. 180-186, 214-217; Bodley, 1990: esp. 94-151; cf. Berreman, 1981a; Berreman, ed., 1981b). It is expressed in rampant technological proliferation and sophistication, in increasingly reckless resource exploitation and foolhardy international adventurism. It has brought about an ever widening gap between the rich and poor nations of the world, and between the rich and poor citizens of virtually every nation in the world including the United States of America. Economists report an increase in the wealth of the most affluent one-third to onefifth of the populations of most of the world's nations since World War II, and 
an increase in the impoverishment of the least affluent one-third to one-fifth of the populations of those nations.

Is it any wonder that some wit in America has asked, "Why is our national product so gross?" and another, "if we're so rich, why aren't we smart?"

To return to South Asia, anthropologist and public health professor John Ratcliffe has argued persuasively to explain why Kerala, the poorest state in India by every "economic indicator," has the highest standard of living in India by every "quality of life indicator:" i.e., infant survival, life expectancy, literacy (especially female literacy), education, low reproductivity (i.e., small family size), nutrition, etc. The reason is primarily that its resources are by far the most equally shared throughout the population when compared to any other Indian state. That is, they have the fewest rich people and the fewest poor people; they have the lowest average income, but they have conspicuously the smallest disparity between those who are most and least affluent (Ratcliffe, 1978; cf, Franke and Chasin, c1989; 1992). Put another way, they have the poorest rich people; the richest poor people.

For similar reasons, as is now widely recognized and amply demonstrated by the experience and research of such organizations as Food First, in such publications as their book Needless Hunger, there is sufficient food for everyone even in famine-prone Bangladesh. It is the grossly unequal distribution of food (including withholding of food for higher prices and export of food for profit, even in famine years) that is the problem (Hartmann and Boyce, 1982; cf. Hartmann and Boyce, 1983).

In a related finding, anthropologists Laura Nader and Stephen Beckerman have concluded in an article entitled "Energy as it Relates to the Quality and Style of Life," that there is no relationship between energy consumption (which is what Gross National Product largely is) and quality of life -- except, of course, for those who sell it (Nader and Beckerman 1978).

\section{ANTHROPOLOGY AS APPLIED SOCIAL SCIENCE}

The great sociologist C. Wright Mills has said that the role of the social scientist, as of any person of knowledge, is to maintain "an adequate definition of reality." He terms this, "the politics of truth:"

\footnotetext{
".... The main tenet of [which] is to find out as much of the truth
}

as he can, and to tell it to the right people, at the right time, and in the right way. Or stated negatively; to deny publicly what he knows to be false whenever it appears in the assertions of no matter whom" (Mills, 1955). that:

He elaborates on this point in The Sociological Imagination, noting

"In a world of widely communicated nonsense, any statement of fact is of moral and political significance. All social scientists, by the fact of their existence, are involved in the struggle between enlightenment and obscurantism. In a world such as ours, to practice social science is, first of all, to practice the politics of truth" (Mills, 1959: 178)

What Mills had to say in this regard -- and it was a very great deal -- is applicable to all socially responsible social scientists, and in fact to all "knowledge workers," as he sometimes called those who deal in a major way with ideas, be they journalists, philosophers, creative writers, teachers, researchers or others. Therefore in his description, he has included sociologists and anthropologists, by defnition as well as explicitly, as knowledge workers. And surely, the politics of truth is -- or ought to be -- the politics of anthropologists, whatever their orientation or specialization. Here, however, will focus on those who are involved in the application of anthropological knowledge, methods and insights to practical affairs: in short, those who may be termed, "applied anthropologists."

It is from the perspective embodied in Mills' writing that I conceive of "applied anthropology," which I view as my discipline's role in public policy formation. It is specifically with reference to that branch of policy making and implementation called "development," that I am speaking here. In fact, there is now a sub-field of anthropology, in America at least, designated: "Development Anthropology."

My own definition of applied anthropology is that it is the application to practical affairs -- particularly to social change -- of insights derived from the comparative, wholistic, contextual study of human beings. It deals with the systems of meanings through which people understand and organize themselves and their experience in relation to their total environment, human and supernatural as well as physical. In short, it deals with both material conditions and social constructions of reality, and the human consequences of both. 
My view of the relationship of anthropology to development, or to any other policy issue, therefore, is to employ what we know or can learn through ethically, as well as scientifically, sound research methods, about the beliefs, values, practices, institutions, and any other learned, shared and transmitted characteristics -- i.e. cultural characteristics -- of the members of a social entity, in order to anticipate and respond to social change and its consequences, in a manner that is in the interests of those people. The italicized terms in the foregoing sentence are the topic of a recent article, "Ethics versus 'Realism' in Anthropology" (Berreman, 1991).

As I see it there are at least two major kinds of ways in which anthropological knowledge is actually applied. (1) That by those who might be described as "human engineers," among whom I would distinguish two sub-varieties: (a) "practicing anthropologists" and, (b) "public interest anthropologists." (2) That by those who might be described as "academic (or, ivory tower) applied anthropologists" (cf. Berreman, 1991).

I will elaborate briefly on these very casually defined categories:

(1) "Human engineers" -- These anthropologists make themselves available as technical advisers to plan, and facilitate accomplishment of the goals of governments, corporations, political parties, NGOs (non-governmental organizations), or other institutions, groups or persons intent on managing and/ or helping people. In short, they stand ready to help people manage other people in order to get the latter to do what the former want them to do: e.g., to acquiesce in government programs, to buy products, to support policies, candidates, parties or regimes, to become vaccinated, stop smoking, join the army or the Peace Corps, fly United, drink Pepsi Cola, practice safe sex, recycle paper, combat sexism, support human rights, free the Palestine, return lands to Native Americans, etc.

Among human engineers I distinguish two subsets: (a) the first, whom I call "vested interest anthropologists" (although they choose to call themselves "practicing anthropologists"), comprises those who choose to sell their skill and knowledge in the marketplace. (b) The second, "public interest anthropologists," are those who opt to work for public interest groups -- some call themselves "advocacy anthropologists," to emphasize their commitment to working as socially responsible advocates of such groups or causes. I hasten to explain that these obviously value-laden categories and their characterizations, reflect my own biased evaluations and the distinction, while intuitively valid, at best describes "central tendencies," rathr than discrete characteristics. Nevertheless, it is the case that some applied anthropologists practice their profession (often with substantial incomes) as professional consultants, either free-lance or in the employ of profit-making corporations or agencies, while others work for public interest groups or NGOs (often living on a shoestring). It is this contrast that I am making here. Those in the former category predominate among "practicing anthropólogists," (there is a professional organization with this title in the United States, a subsidiary of the Society for Applied Anthropology).

There is as yet no professional organization for public interest or advocacy anthropologists, al though there are a number of specific organizations comprising people so motivated: The International Work Group for Indigenous Affairs (IWGIA) of Copenhagen, Cultural Survival Inc. of Cambridge, Massachusetts, various regional, national and ethnic "Information Groups," and the late, lamented Anthropology Resource Center of Boston (whose founder and driving force, Shelton Davis, together with his colleague Robert Matthews, coined the term "public interest anthropology" [Davis and Matthews, 1979]), are among those which come to mind as examples.

A few anthropologists have worked in the employ of indigenous or minority peoples, either for particular groups such as an American Indian nation or tribe. By way of examples I will mention two such people whom I happen to have known personally. One, from many years ago, is Hiroto Zakoji, then recently of the University of Oregon, who was employed by the Klamath Indian tribe of Oregon, to help them deal with the problems attending termination of their reservation status. A recent example is Triloki Pandey of the University of California, Santa Cruz, one of the foremost contemporary anthropological authorities on the Zuni of the American southwest, who served for several years recently as a consultant to the Zuni in their land claims case involving the Hopi and the U.S. Govemment, and whose work was lauded by each of the litigating parties. For further examples see: Robert Paine's edited volume, Advocacy and Anthropology (1985), especially Maybury-Lewis's essay therein, "A Special Sort of Pleading: Anthropology at the Service of Ethnic Groups" (1985), and John Bodley's edited volume, Tribal Peoples and Development Issues : A Global Overview (1988) in which, incidentally, Maybury-Lewis's essay is reprinted.

Some of those who work most directly for emancipation of indigenous and minority ethnic groups have come to refer to their activities as "Liberation Anthropology" -- a felicitous term I first heard from Gerrit Huizer, deriving from the "Liberation Theology" of human rights activist Catholic clergy in Latin 
America (see: Huizer, 1979). Many of these appear or are cited in the pages of Bodley's volume cited in the preceding paragraph.

(2) "Traditional academic or 'ivory tower' applied anthropologists" -- This second major category within applied anthropology is more frequently encountered in teaching and research than in direct application, hence its description by its detractors, as "ivory tower." It tends to focus on general principles of the application of anthropological insights to human problems, employing specific cases to discover and illustrate these principles. This focus is associated with a strong tendency to do research (in order to discover such principles), and to teach (in order to train others to be able to apply those principles in practice). This kind of applied anthropology, therefore deals more with knowledge than with practice, but not simply knowledge for its own sakè. Rather, its advocates would say that it is in the Enlightenment tradition of knowledge pursued and taught for the enhancement of the quality of human life in a very direct and practical way (cf. Berreman, 1968b).

Anthropologists, whether traditional or applied, whether "practicing" or "ivory tower", whether working in the public interest or in the vested interest, all generally believe that their discipline has something unique to offer among the applied social sciences because its distinctive philosophy and methods of research give them an understanding of a people's ways of life - at once experimential, wholistic and contextual -- that is obtainable in no other way. At their best, anthropologists do their research by putting themselves into the circumstances of the lives of those they seek to understand, through the method of participant-observation-- that is, by sharing with people, in so far as possible, their daily lives for extended periods of time. The understanding comes about through the empathy that results from intensive participation and observation. Thus meaning and its contextual variations are learned to an extent unlikely in any other way short of membership in the group -- and in ways not unlike those ways in which anyone is socialized into an unfamiliar group. In this manner we anthropologists seek to learn the culture in a way not wholly unlike the socialization of an insider. The ultimate accomplishment, it is sometimes said, is not when the researcher no longer makes mistakes, but when the mistakes made are of the sort that people within the society occasionally make. In short, we seek to derive an understanding of the world of the people we study that is consistent with their own understanding -- a definition of reality that is adequate to their experience.

In this way, applied anthropologists hope to be able to provide communication links between people at the grass roots in their daily lives, on the one hand, and on the other hand those -- such as developers and policy makers -- whose decisions and actions are likely to fatefully affect their lives. That is, we seek to apply what we learn to helping enable people in these two interdependent human roles to make significant contact in order that they may have a basis for understanding one another, in the hope that they will be able to reach a creative or at least viable consensus on how they may interact most productively. Without the kind of understanding we seek, without the input we hope to make in policy formation, there is bound to be the kind of frustration, conflict and failure that so often characterizes development efforts worldwide -- efforts which, in fact, have given the very term "development" the kind of negative connotation in most social science quarters that is so vividly exemplified by the writings of Gunder Frank and Ivan Illich, cited above.

In their brilliant book, Villagers, Forests and Foresters, comprising a case study of community forestry in Nepal, D.A. Gilmour and R.J. Fisher (1991; See also, Ives and Messerli, 1989)) make the point strongly that conflict between forest administrators and forest users is inimical to resource management; observing that while conflict cannot be altogether avoided, "... a high degree of consensus is probably necessary for effective common property management" (p. 48). The importance of this modest statement cannot be overestimated in its relevance to development, to policy making at any level, any more than it can to forest resource management. Consensus building, like its companion process, compromise, requires mutual respect and understanding, which in turn require common knowledge and shared definitions of the situation at hand. It is to these processes that anthropologists have the most to offer -- I venture to claim in fact that we have something unique to offer -- as a result of our intimate, in-depth ethnographic knowledge and understanding. Our understanding attempts to go beyond the goals of a project and the fears or reservations of a user group, to the long range and direct consequences that can be anticipated but are likely to be overlooked or unrecognized by either or both parties to the project. This, too, requires ethnographic understanding. Technical expertise alone is simply not enough and may in fact be deceptive in obscuring the most important issues of all -- the human problems.

I believe that a major reason why Gilmour and Fisher's book comprises such an important contribution -- combining as it does, theory and method with a detailed empirical case study of community forestry in two districts of Nepal - is that its authors combine Gilmour's bio-technical expertise as forester, and 
Fisher's socio-cultural expertise as anthropologist, while the two obviously share experience, knowledge, values and mutual respect, resulting in a crucial consensus of their own.

\section{"SUCCESSFUL" DEVELOPMENT : OBSTACLES AND STRATEGIES}

In view of what I have said thus far, where are we in our consideration of development, public policy and anthropology?

Development is by definition a value judgement: an assertion about what is good, desirable, efficient and perhaps inevitable. Its dilemma is that one person's -- or group's -- progress may be another's regress or devastation. One man's gain is likely to be another man's loss, and is even more likely to be another woman's loss.

If development is to be in the public interest, it must be accountable to the public. That means the entire public including people of all ethnic groups, castes, classes, genders, occupations, religions, languages, etc. Presumably that is what democracy, to which this nation is now committed, is about. This means it must be planned in consultation with the people who constitute the society, and beyond that, in partnership with them, and even beyond that, in response to them and to their concerns. This is the fundamental dilemma of development, because every complex society is made up not only of diverse groups but of diverse interest groups. In South Asia this dilemma takes the especially vivid form of the caste system, analogous to the system of racial discrimination in America.

A caste system is a system of social, economic and political hierarchy made up of groups each with distinct cultures, traditions and histories -- and therefore definable as ethnic groups -- but which differ from other ethnic groupings by being based entirely on birth, i.e., on shared ancestry. As anthropologists put it, caste membership is "birth-ascribed." 2

Because a caste system comprises a hierarchy of power and privilege -- of vulnerability and deprivation -- as well as of symbolic values, it entails a hierarchy of conflicting interests; what is in the interest of one or some castes is likely to be against the interest of other(s). These are not trivial matters, and often in fact are matters of livelihood, or indeed of life itself. Therefore, any development program is certain to exacerbate intercaste conflicts and to be undermined thereby, for it will be perceived to be beneficial to (and/or controlled or influenced by) one or more castes at the expense of others. Because this is an intrinsic feature of the caste system, and because that system is virtually universal among the dominant sectors of South Asian societies, it constitutes a true and tragic dilemma.

Those involved in development or self-help projects will not improve their chances of success by ignoring this dilemma. The best they can do is to facilitate reasoned discourse among the interest groups -- the castes -- in order to develop an adequate working consensus. This can be attempted through appeals to relevant legal and ideological doctrines which counter competitive, confrontational casteism. Such doctrines can often be found in the religious and ethical traditions of even the most caste-bound or racist of societies and may be invoked even when deeply buried, widely ignored or contradicted. In this way, common values and interests may be discovered which can form the bases for compromise, cooperation, conflict resolution and eventual consensus building -- even mutual empathy -- based on the lowest common deriominator of shared interests of the larger community.

Most development projects retreat into supporting caste-specific projects which do not affect members of competing interest groups -- usually supporting projects which benefit the "dominant caste(s)," i.e., those economically, politically and socially most advantaged (Srinivas, 1959; cf. Berreman, 1963a: 205-209). The rationale may be some hazy version of "trickle down economics," or a more pragmatic decision to work with those most able to participate in development and least likely to be challenged by others -- which is a decision to help those who least need it but are most likely to produce "results." These convoluted, devastating, intractable and pervasive consequences of the caste system are, and will long remain, the Achilles heel of concerted, democratic community action in South Asia, for they minimize (if they do not wholly preclude) the possibility of a supportive consensus, and therefore success for such action.

A close second in the list of daunting obstacles to effective development programs -- less daunting, perhaps, in the Himalayas than in the adjacent northem Indian and Nepalese plains and terai -- is gender discrimination. Hierarchy based on gender works quite differently than that based on caste, however, because both genders are represented in every community, every caste, every family with the common socialization and cross-cutting common interests that fact implies. As a result, gender presents different -- and I would venture to say, less ominous -- challenges to development than does caste. I cannot go further into this important issue here, but I have done so elsewhere (Berreman, 1989; 1992). 
In any case, development projects routinely fail for want of public support. In addition to failure to achieve consensus (as described above) that failure usually results from the fact that people have not been convinced of the relevance of the projects to their lives and concerns. They more often than not see them simply as instances of familiar and resented bureaucratic intrusions on their autonomy and impositions on their time and energy - useless at best (as in the case of a program to teach improved farming methods, including the totally inappropriate Japanese method of rice cultivation, to the Garhwali subsistence farmers of the Indian Himalayas among whom I have done research [alluded $t$ in Berreman, 1963a:289; cf. Berreman, 1963b), and devastatingly damaging at worst (as in the case of construction of the huge Tehri Dam in Garhwal, perceived [accurately] by the rural Garhwali people, many of whom it will displace, as destructive, dangerous and useless to them [Tiwari, 1987]).

For any chance of success, people's participation in the development process must be secured at every step of the way: in deciding whether development is needed and wanted, and if so what kind of development it should be, i.e., what needs or wants are to be met; in planning how they shall be met; in implementing the process of meeting them; in assessing the results; in revision of the program in view of assessments of its results, etc. If people withdraw their support of a program so instituted, it need not be summarily dropped, but their support must be won if the project is to be implemented or continued. This cannot be accomplished through bureaucratic bullying, but only through reasoned argument supported by evidence, accompanied by a willingness to listen to learn, to compromise or back down as people's responses dictate. The veto power of the people should be assured and honored. In short, respect for the wisdom and experience of those potentially involved planned change is essential to its success.

Rural people may be unlettered, they may even be uniformed or misinformed on an issue, but they are not ignorant or inexperienced, certainly not with reference to their own environment, livelihood and way of life. They have acquired their knowledge and skills over many generations, and have developed sophisticated methods for managing their environment and social relations (for many examples see Tamang, Gill and Thapa, eds. 1993, and for an excellent brief statement therein on implications for policy making, see Gill's essay therein (Gill, 1993; cf. Chhetri, 1994; Fisher, 1989; Gilmour, 1990). Their knowledge is more grounded, tested and relevant than that of planners, politicians, administrators -- or anthropologists. Like anyone else, they have to be convinced of the value of a project or project in order to support it. In order to be convinced, they must be taken fully into the confidence of policy makers and implementers and fully into the policy making and implementing process including being given decision-making power. These are requirements unfamiliar and often unpalatable to bureaucrats and experts, but they have to be learned and practiced if planning and development are to be appropriate, accepted and effective.

In addition, those who do the planning, implementing and administering must be held accountable to the "user group" --- that is, to the people whom they serve and who employ them or at least make their employment possible. The "developers" must learn to define themselves as public servants and act accordingly, rather than as authority figures or bureaucratic superiors. Those for whom they plan are not to be seen as target populations but as clients to be served through close and continuous consultation.

As most of us have learned by now, development policy cannot be successfully imposed from above (e.g., from government), nor from outside (e.g., from such funding sources such as the World Bank, the International Monetary Fund, the U.S. Agency for International Development (AID), or the big international foundations). The notion that those who pay the piper are entitled to call the tune, is now simply inapplicable, irrelevant and in fact counterproductive to development -- or for any issue of public policy. Development funds allocated conditionally are clearly coercive -- they control development, they buy people, their lives and their resources. I believe they should be rejected, from whatever source they may come and however attractive they may be, however benevolently they may seem to be offered. If money is to be given, it should be given freely, with no strings attached, in trust and with confidence that people are best able to define their own needs. This would no doubt seem quizzical and even frightening to donors, but they need not worry; people at the grass roots could hardly do worse than US-AID, the World Bank, and others too numerous and some too sensitive to mention, have done. In fact, the most effective kind of development may be that which does not entail the bestowal of money at all. Those promoting development might best limit themselves to the role of facilitators, advisors available to those who may seek their help, to the extent and for the purposes that they the seekers define. They could help people figure out how to accomplish what they want and need, including how to secure their own financing. It would be worth a try, certainly so if sustainability of development is an issue--as it must always be, because outside funding is uncertain and ephemeral. I have been told of at least one reportedly successful such project, initiated by the United Mission to Nepal in far western Nepal. 
But to return to the immediate "realities" of development policy and practice: we needn't hold our collective breaths -- money is unlikely to be of fered without strings; projects are unlikely to be widely promoted free of political pressure and without money as an inducement and mechanism for change. We live in a mercantile world in which there truly is no such a thing as a free lunch. Governments want their supporters, foundations want their profits and tax writeoffs, missionaries want their converts. Even the apparently benign Peace Corps was founded and sustained explicitly as a weapon against Communism, to be employed in those nations where a threat of Communism was believed to exist -- a threat which, though "real," was deemed weak enough that something as inexpensive as the Peace Corps was thought sufficient to sustain an antiCommunist government, and perhaps to serve as well as a palliative -- and diversion -- for restless American youth and anti-Vietnam war activists (Berreman, 1968a; Windmiller, 1970).

\section{CONCLUSION : THE ROLE AND PROMISE OF ANTHROPOLOGY IN DEVELOPMENT}

I have now come full circle in my discussion: I have claimed that anthropologists have unique opportunities through their training and research experience, to understand peoples, their ways of life, the social and cultural dynamics of their societies, their definitions of their circumstances, and their perceptions of how to improve their lives.

With that understanding and the information which supports it, anthropologists working together with people and their governments, have the potential to be effective social and cultural interpreters or mediators in pursuit of a productive consensus on programs and policies initiated by and genuinely benefitting the people directly affected and their nations at large, and beyond. As such, they should be able to be both practically and morally -- and in any case humanly -- useful as advisor-informants on matters social and cultural by helping to generate adequate definitions of the realities confronting people, to formulate positive responses to those problems, and to anticipate consequences and implications of proposed courses of acton.

That is, anthropologists can be expected to advise, on the basis of sound, empirically and experientially derived knowledge, what the consequences of particular policy decisions are likely to be as they affect particular people in particular circumstances. This, I think, is what is most surely lacking in development planning and in public policy-making in general, be it in Nepal or the United States or anywhere else.

Too often bureaucrats and planners are entrusted with deciding for people what will be good for them -- often for people a most wholly unknown to those making the decisions. Policies can be effectively formulated only in terms of what people themselves want and need in the context of the total circumstances of their lives. Developers should limit themselves to the role of technical advisers.

As I have argued here, I am convinced that anthropologists -- and here I am thinking primarily of Nepalese anthropologists, of whom a substantial trained and experienced cadre has been developing in recent years -- are in a position to provide the information and understanding which alone can make for appropriate policies and plans for a society as culturally diverse as Nepal -- plans and policies which can work for the benefit of all.

Administrators should grasp the opportunity to make use of this potentially effective, but largely untapped, domestic human resource for bringing into reality the great promise democracy holds for this nation and all of its people. The first steps are up to the anthropologists: to demonstrate to those who govern, to those who provide funds, and to the society at large, the relevance of the resources they command to the problems confronting the people and the nation.

I believe Nepalese anthropologists have already taken the initial steps, exemplified by the work of those I have met and worked with this year. I hope that what I have said here may in its small way, inspire further steps in that direction, and may also alert those in positions of influence and in the general public to recognize, appreciate and respond to those steps by incorporating these people and their skills fully into policy making and implementation of the development process in Nepal.

\section{NOTES:}

1. Lecture sponsored by: Central Department of Sociology/Anthropology, Tribhuvan University, the Sociological/Anthropological Society of Nepal, and Winrock International. Delivered in abbreviated form at Winrock International, Kathmandu, March 25, 1994.

2. Caste and its consequences have been a major focus of my anthropological 
research -- the major focus for the first 25 years (1957-1982) of my life as a South Asianist anthropologist. For the benefit of the curious reader, I will list here (and in the "References Cited" section of this paper), some of the results of that research: Berreman, 1960; 1963a; 1963b; 1965; 1966; 1967, 1968c; 1971a; 1971b; 1972a; 1972b; 1973; 1976; 1977; 1979b; 1981b; 1983a; 1983b. For an excellent, brief overview of interpretations of India's caste system, see Kolenda, 1978.

\section{REFERENCE CITED\#}

Berreman, Gerald D.

* 1960

Caste in India and the United States. American Journal of Sociology. 66:120-127. Republished in India, see Berreman, 1979b (cited below): 1-13.

* $1963 a$

Hindus of the Himalayas. Brekeley: University of California Press. Second edition, enlarged (pagination unchanged through p. 357): 1972, Hindus of the Himalayas: Ethnography and Change. Brekcley: University of California Press.

(Both editions have been published also in India by Oxford University Press, New Delhi, with publication dates of 1963 and 1993, respectively.)

* $1963 b$

Caste and community development. Human Organization. 22:90-94. Republished in India, see Berreman, 1979b (cited below):30-41.

\# Citations preceded by an asterisk $\left({ }^{*}\right)$ refer to books donated to the Tribhuvan University Library, Junc 1994. Those preceded by a double asterisk $(* *)$ refer to individual reprinted articles donated to that library. An effort has been made here to refer to literature available in Kathmandu and/ effort has been made here my own work extensively; not out of egocentrism, but because much of it is available in Kathmandu and, based as it is on research in the Himalayas, it is directly relevant to Nepal.
* $1968 \mathrm{c}$

The study of caste ranking in India. Southwestern Journal of Anthropology. 21:115-129. Republished in India, see Berreman, $1979 b$ (cited below): 42-57.

Caste in cross-cultural perspective. Japan's Invisible Race: Caste in Culture and Personality (G. DeVos and $\mathrm{H}$. Wagatsuma, eds.) Berkeley: University of California Press. Pp. 275-324.

Caste as social process. Southwestern Journal of Anthropology. 23:351-370. Republished in India, see Berreman, 1979b (cited below): 96-115.

The Peace Corps: a dream betrayed. The Nation. Feb. 26, 1968, 206 (9): 263-268. Republished in India, see Berreman, 1981a (cited below): 154 167.

Is anthropology alive? Social responsibility in social anthropology. Current Anthropology. 9 (5):391-396. Republished in India, see Berreman, 1981a (cited below): 30-46.

Caste: the concept. The International Encyclopedia of the Social Sciences (D. Sills, ed.) New York: Macmillan and Free Press. Vol. II, pp. 333-339.

Academic colonialism: not so innocent abroad. The Naton. Nov. 10, 1969, 209 (16:) 505-508. Republished in India, see Berreman, 1981a (cited below): 194-202.

The Brahmanical view of caste. Contributions to Indian Sociology. 5:18-25. Republished in India, see Berreman, $1979 \mathrm{~b}$ (cited below): 155-163.

* 1971b Self, situation and escape from stigmatized ethnic identity. 1971 Yearbook of the Ethnographic Museum, University of Oslo. Oslo: Universitetsforlaget. Pp. 11-25. Republished in India, see Berreman, 1979b (cited below): 164 177. 
Race, caste and other invidious distinctions in social stratification. Race (Special issue: Race and Stratification, W. Runciman, ed.) 23 (4): 385-414 Republished in India, see Berreman, $1979 b$ (cited below): 178-219.

Social categories and social interaction in urban India. American Anthropologist. 74(3) 567-586. Republished in India, see Berreman, 1979 b (cited below): 124-154.

Caste in the Modern World. Morristown, New Jersey: General Learning Press.

Social mobility and change in India's caste society. Responses to Change (G. DeVos, ed.). New York: D. Van Nostrand. Pp. 294-322.

Demography, domestic economy and change in the western Himalayas. The Eastern Anthropologist. 30(2) 157-192. (Alsopublished in somewhat revised form as: Ecology, demography and domestic strategies in the Western Himalayas. Journal of Anthropological Research. 34:326-368.)

Himachal: Science, People and Progress. (IWGIA Document 36.) Copenhagen: International Work Group on Indigenous Affairs.

Caste and Other Inequities: Essays on Inequality. Meerut: Folklore Institute, and New Delhi: Manohar Book Service.

Are human rights merely a politicized luxury in the world today? Anthropology and Humanism Quarterly (Tallahassee, Florida): 5(1):2-13. Republished in India, see Berreman, 1981a (cited below): 268-298.

The Politics of Truth: Essays in Critical Anthropology. New Delhi: South Asian Publishers.

Social inequality: a cross-cultural analysis. Social
Inequality: Comparative and Development Approaches (G. Berreman, ed.). New York: Academic Press. Pp. 3-40. An earlier version was published in India, see Berreman, 1979b (cited above): $288-312$.

* 1983 a Identity definition, assertion and politicization in the Central Himalaya [Chipko]. Identity: Personal and Socio-Cultural (A. Jacobson-Widding, ed.). Uppsala Studies in Cultural Anthropology 5. Stockholm: Almqvist and Wiksell International; Atlantic Highlands, N.J.: Humanities Press. Pp. 289-318.

* 1983b

The evolutionary status of caste in peasant India. Anthropology of Peasantry (J. Mencher, ed.) Bombay: Somaiya Publications. Pp. 237-250. Republished in India, see Berreman, 1979 b (cited above): 313-325.

** 1989 Chipko: a movement to save the Himalayan environment and people. Contemporary Indian Tradition: Voices on Culture, Nature, and the Challenge of Change. (C. Borden, ed.) Washington D.C.: Smithsonian Institution Press. Pp. 239-266.

** 1991 Ethics versus "realism" in anthropology. Ethics and the Profession of Anthropology: Dialogue for a New Era. (C. Fluehr-Lobban, ed.) Philadelphia: University of Pennsylvania. Pp. 36-71.

** 1992 Sanskritization as gender oppression in India. Sex and Gender Hierarchies. (B. Miller, ed.) New York: Cambridge University Press. Pp. 366-392.

Berreman, Gerald D. (ed.)

* 1981

Social Inequality: Comparative andDevelopmental Approaches. New York: Academic Press.

Bhandari, Bishnu

1990
The past and future of sociology in Nepal. Occasional Papers in Sociology and Anthropology 
(Central Department of Sociology / Anthropology, Tribhuvan University, Kirtipur). 2: 13-23.

Bodley, John H.

* 1976

Anthropology and Contemporary Human Problems. Menlo Park, Califomia: Cummings.

* 1990 Victims of Progress (3rd edition). Mountain View, California: Mayfield.

Bodley, John H. (ed.)

* 1988

Tribal Peoples and Development Issues: A Global Overview. Mountain View, California: Mayfield.

Campbell, J. Gabriel, Ramesh Shrestha and Linda Stone 1979

The Use and Misuse of Social Science Research in Nepal. Kathmandu: Research Center for Nepal and Asian Studies; His Majesty's Government Press.

Chhetri, Ram B.

1994

Indigenous and community forestry management systems: reviewing their strengths and weaknesses. Revised version of a paper presented at: Conference on the Anthropology of Nepal: People, Problems and Processes. Kathmandu, 7-14 September 1992. Publication forthcoming.

Cultural Survival Quarterly 1976 .

Present Eighteen volumes of this anthropological journal have appeared through 1994, almost all of which include articles describing and analyzing the impact of "development" on "indigenous," "tribal," "peasant" and "minority" peoples. Its masthead states: "The Quarterly serves to inform the general public and policy makers in the United States and abroad to stimulate action on behalf of tribal people and ethnic minorities." It also lists and/or distributes other publications with simlar concerns, e.g., those of the International Work Group on Indigenous Affairs, the Minority Rights Group, and the now defunct Anthropology Resource Centre. Its address is: Cultural Survival Inc., 53-A Church St., Cambridge, MA 02138, USA.
Davis, Shelton and Robert Matthews

1979

Anthropology Resource Centre: public interest anthropology -- beyond the bureaucratic ethos. Practicing Anthropology 1(3): $5 \mathrm{ff}$.

Fisher, RJ. 1989

Indigenous Systems of Common Property Forest Management in Nepal. Working Paper No. 18 (December 1989). East-West Environment and Policy Institute. East-West Center, Honolulu, Hawaii.

Frank, A. Gunder 1967

Capitalism and Underdevelopment in Latin America. New York: Monthly Review Press.

1969 Latin America: Underdevelopment or Revolution. New York: Monthly Review Press.

Franke, Richard

1977

Miracle seeds and shattered dreams in Java. Readings in Anthropology. Guilford, Connecticut: Dushkin. Pp. 197-201. (Summarized in Kottak, 1987a: pp. 342-345; 1987b: pp. 494-497 [both cited below].)

Franke, Richard W. and Barbara H. Chasin

c1989 Kerala: Radical Reform as Development in an Indian State. (Food First Development Report no. 6) San Francisco: The Institute for Food and Development Policy.

1992 Kerala, Development Through Radical Reform. New Delhi: Promilla (in collaboration with the Institute for Food and Development Policy, San Francisco.)

Gill, Gerard J.

1993 Indigenous systems in agriculture and natural resource management: the policy dimension. In D. Tamang, G. Gill and G. Thapa (eds.), cited below. Pp. 3-12. 
Gilmour, D.A 1990

Resource availability and indigenous forest management systems in Nepal. Society and Natural Resources. 3:145-158.

Gilmour, D.A. and R.J. Fisher

1991

Villagers, Forests and Foresters: The Philosophy, Process and Practice of Community Forestry in Nepal. Kathmandu: Sahayogi Press.

Gross, Daniel

1971

The great sisal scheme. Natural History. March 1971:49-55. (Summarized in Kottak, 1987a: pp. 340-342; 1987b: pp. 492-494 [both cited below].)

Hartmann, Betsy and James Boyce

* 1982 Needless Hunger:VoicesfromaBangladeshVillage (Revised edition). San Francisco: Institute for Food and Development Policy.

1983 A Quiet Violence: A View from a Bangladesh Village. San Francisco: Institute for Food and Development Policy.

Huizer, Gerri

1979

Anthropology and politics: From naivete toward liberation? The Politics of Anthropology (G. Huizer and B. Mannheim, eds.). The Hague: Mouton. Pp. 3-41.

Illich, Ivan

1969

Outwitting the 'developed' countries, The New York Review, November 6, 1969: 18-22.

Ives, Jack D. and Bruno Messerli

The Himalayan Dilemma: Reconciling Development and Conservation. The United Nations University. London and New York: Routledge.

Kardiner, Abraham and Lionel Ovesey

The Mark of Oppression. Cleveland, Ohio: The World Publishing Company.
Khanal, Ajaya Bhadra

1994

Kolenda, Pauline M

* 1978

Kottak, Conrad Philip

* 1987a

* 1987b

Lewis, David 85

A special sort of pleading: anthropology at the

Messerschmidt, Donald A. 1992

\section{Mills, C. Wright 1955}

* 1959 service of ethnic groups. Advocacy and Anthropology (Robert Paine, ed.). Memorial University of Newfoundland, St. Johns: Institute of Social and Economic Research. Pp. 130-149.

In search of a grander faith, Weekly Magazine of The Kathmandu Post.February 27, 1994: 1 and 4. Solidarity. Menlo Park, California: BenjaminCummings.

Cultural Anthropology (fourth edition). New York: Random House.

Anthropology: The Exploration of Human Diversity (fourth editin). New York: Random House.

(Note: 1987a is a textbook on cultural anthropology, $1987 \mathrm{~b}$ is on the entire field of anthropology; both include the same material on cultural anthropology.)

The uses of anthropology in agro-forestry research and development: approaches to anthropological forestry. Social Science Applications in Asian Agroforestry (W.R. Burch and J.K. Parker, eds.). Columbus, Missouri: South Asia Books, and Winrock International. Pp. 145-179.

On knowledge and power. Power, Politics and People: The Collected Essays of C. Wright Mills (I.L. Horowitz, ed.). New York: Ballentine Books. Pp. 599-613.

The Sociological Imagination. London, Oxford, New York: Oxford University Press.
Caste in Contemporary India: Beyond Organic 
1978 Energy as it relates to the quality and style of life. Annual Review of Energy. (J.M. Hollander, M.K. Simmons and D.O. Woods, eds.), Palo Alto, California: Annual Reviews Press. Vol. 3, pp. 1-28.

Paine, Robert (ed.) 1985

Advocacy and Anthropology. Memorial University of Newfoundland. St. Johns: Institute of Social and Economic Research.

Ratcliffe, John ** 1978

Saberwal, Satish (ed.)

1968

Social justice and the demographic transition: lessons from India's Kerala state. International Journal of Health Services. 8(1): 123-144.

Academic colonialism: a symposium on the influences which destroy intellectual independence, Seminar (New Delhi), No. 112: December 1968.

Shah, Saubhagya

Srinivas, M.N.

1959

'Western bias behind failure of development projects.' The Rising Nepal. March 26, 1994: pp. 1 and 8.

The dominant caste in Rampura. American Anthropologist. 61:1-16.

Tamang, Davika, G.J. Gill and G.B. Thapa (eds.)

Indigeneous Management of Natural Resources in Nepal. Kathmandu: His Majesty's Govemment, Ministry of Agriculture, and Winrock International.

Tiwari, Rajiv

1987

Tehri: temple or tomb? Himal, Vol. 0, No. 0. May, 1987.

Windmiller, Marshall 1970

The Peace Corps and PaxAmericana. Washington, D.C.: Public Affairs Press.

\section{DEVELOPMENT ISSUES RAISED DURING THE "PEOPLE'S MOVEMENT" OF 1990 ${ }^{1}$}

\author{
Krishna B. Bhattachan
}

To get more insight into the relation of the "people's movement" to contemporary problems of underdevelopment in Nepal, it will be of great help to look at political pamphlets distributed by political parties and professional groups. In this paper I will show that many development issues were raised in the political pamphlets released by political parties and professional organizations. At the end, I will analyze the two dominant beliefs of the Nepalese public about the current situation of underdevelopment and future prospects of development of the country.

\section{Development Issues Raised in the Political Documents} Released by Major Political Parties

Political pamphlets played a very significant role in Nepal under the repressive reign of the autocratic partyless Panchayat regime. Political parties were banned in Nepal by the late King Mahendra in 1960; later by the 1962 Constitution. Political meetings, including mass meetings and street demonstrations against the partyless Panchayat system and the king, were outlawed. In the beginning of the "people's movement" many political leaders and political activists were imprisoned for "public security" reasons. Most of the national and local newspaper and newsmagazine were banned and many editors were imprisoned. All the international newspapers were confiscated at the entry ports. In such adverse circumstances, one effective way to break the barrier against spreading the messages of political parties was the wide circulation of political pamphlets, which are not expensive and easy to distribute. Itseffectiveness depends on how the people and public could relate their problems and demands to those mentioned in the pamphlets. If the pamphlets hit the right chord of the people's sentiment, they could help them to engage in public debate about matters of common concern. 